\title{
Comparison of Complications in Elderly Patients Undergoing Coronary Artery Bypass Surgery with or without Use of the Left Internal Thoracic Artery
}

\author{
Mustafa Aldemir ${ }^{1}$, Devrim Eroğlu², Fahri Adalı1, Mustafa Emmiler ${ }^{3}$ \\ ${ }_{1}^{1}$ Kocatepe University Faculty of Medicine, Department of Cardiovasculer Surgery, Afyonkarahisar, Turkey \\ ${ }^{2}$ Çorum Government Hospital, Clinic of Cardiovascular Surgery, Çorum, Turkey \\ 3 Antalya Education and Research Hospital, Clinic of Cardiovascular Surgery, Antalya, Turkey
}

\begin{abstract}
Introduction: This study aimed to compare postoperative complications in elderly patients who underwent coronary artery bypass grafting surgery with or without use of the left internal thoracic artery.

Patients and Methods: In this retrospective clinical study, 40 patients over 75 years old undergoing coronary artery bypass grafting surgery between September 2011 and December 2013 in our clinic were included. Twenty of the patients underwent coronary surgery with LITA and the other 20 patients underwent without LITA. We compared the two groups on the basis of postoperative mechanical complications.

Results: Postoperative pneumothorax was seen in 3 patients $(15 \%, \mathrm{p}=0.03)$ who had undergone coronary artery surgery with LITA. Sternal dehiscence was seen in one patient $(5 \%, \mathrm{p}=0.047)$ and sternal infection was seen in one other patient $(5 \%, \mathrm{p}=0.047)$ in whom LITA was used. None of these complications were seen in patients in whom LITA was not used.

Conclusion: Postoperative complications such as pneumothorax, sternal dehiscence and sternal infection were more common in elderly patients in whom LITA was used. However, in consideration of the important superiorities of LITA, this graft cannot be easily abandoned. In conclusion, if the required measures are taken in the elderly without diabetes mellitus, osteoporosis, pre-operative pulmonary disease which would negatively affect the post-operative prognosis, complications related with LITA grafting would not be as serious as to refrain from using this graft in elderly patients.
\end{abstract}

Key Words: Left internal thoracic artery; elderly; coronary artery by-pass

\section{Sol İnternal Torasik Arter Kullanılarak ve Kullanılmayarak Koroner Arter Bypass Cerrahisine Giden Yaşlı Hastalarda Komplikasyonların Karşılaştırılması}

\section{ÖZET}

Giriş: $\mathrm{Bu}$ çalışma ile koroner arter bypass cerrahisine giden yaşlı hastalarda, sol internal torasik arter grefti kullanılanlar ile kulanılmayanların postoperatif komplikasyonlar açısından karşılaştırılması amaçlanmıştır. Hastalar ve Yöntem: Kliniğimizde Eylül 2011 ile Aralık 2013 tarihleri arasında koroner bypass cerrahisine giden 75 yaş üstü hastalardan sol internal torsik arter kulanılan 20 hasta ve kullanılmayan 20 hasta retrospektif olarak değerlendirilmiştir. Toplam 40 hasta sol internal torasik arter grefti hazırlanan grup 1 ve hazırlanmayan grup 2 olmak üzere postoperatif mekanik komplikasyonlar açısından karşılaştırılmıştır.

Bulgular: Postoperatif pnömotorax, LİTA kullanılan grupta 3 hastada $(\% 15 \mathrm{p}=0,03)$, sternal dehiscence ve sternal enfeksiyon ise yine LITA kullanılan grupta birer hastada $(\% 5, \mathrm{p}=0,047)$ görülürken LITAA kullanılmayan grupta bu komplikasyonlar hiçbir hastada tesbit edilmedi.

Sonuç: Sol internal torasik arter grefti hazırlanan yaşlı hastalarda pnömotorax, sternal dehiscence ve sternal enfeksiyon gibi postoperatif komplikasyonlar daha yaygındı. Ancak LİTA grefti çok önemli üstünlükleri düşünüldüğünde kolay vazgeçilebilecek bir greft değildir. Sonuç olarak, diabetes mellitus, osteoporozis, preoperatif pulmoner hastalı gibi postoperatif dönemde prognozu olumsuz etkileyebilecek sorunları olmayan yaşlı hastalarda gerekli önlemler alındığında, LİTA greft hazırlanmasına bağlı komplikasyonların, yaşlılarda bu greftin kullanımının kısıtlanmasını gerektirecek düzeyde olmadığını düşünmekteyiz.

Anahtar Kelimeler: Sol internal torasik arter; yaşlı; koroner by-pass

Correspondence

\section{Mustafa Aldemir}

E-mail: draldemir@yahoo.com Submitted: 29.05 .2014 Accepted: 27.06 .2014

(a) Copyright 2014 by Koşuyolu Heart Journal - Available on-line at www.kosuyolukalpdergisi.com

\section{INTRODUCTION}

The worldwide population is getting older and more elderly patients are undergoing coronary artery by-pass grafting (CABG) surgery. Comorbidities, such as renal failure, peripheral vascular disease, diabetes mellitus, left ventricular dysfunction, pulmonary disease and history of cerebrovascular accident, expectedly, are more common among this elderly surgical population(1). Because of these 
comorbidities, the elderly population is exposed to a high rate of postoperative complications(2). One of the risk factors for poor outcome after CABG is actually old age alone(1).

The left internal thoracic artery (LITA) graft has a key role in better outcomes of coronary artery by-pass grafting surgery. It has the highest patency rates among all other arterial or venous grafts(3). But at the same time, its harvesting may cause some early adverse outcomes, such as bleeding complication, sternal dehiscence, sternal wound infection and pulmonary complications. Because of these early complications related to harvesting of the LITA, many cardiac surgeons may avoid using it in elderly patients. In this study, we compared elderly patients who had undergone CABG with or without a LITA graft on the basis of postoperative complications. The question to be answered was whether LITA use should be restricted to only young patients or whether it may also be used in elderly patients, with respect to its unique complications.

\section{PATIENTS and METHODS}

\section{Study Design}

This retrospective clinical study was performed on 40 patients who had undergone isolated CABG surgery at our institution, Kocatepe University, Department of Cardiovascular Surgery, Afyonkarahisar, Türkiye, between September 2011 and December 2013. This clinical retrospective study was approved by the local ethics committee of the Afyon Kocatepe University Faculty of Medicine. All the patients had coronary artery disease with a varying degree of stenosis of the left anterior descending coronary artery. Patients having left main or left main equivalent coronary artery disease were also included in the study. The details of the 40 elderly $(\geq 75)$ cases during the first month of the operation were collected retrospectively from a computerized clinical database and archived patient files. We selectively collected the data for 20 patients (group 1, n=20) who underwent CABG with LITA and another 20 patients (group 2, $\mathrm{n}=20$ ) without LITA.

\section{Data Collection and Definitions}

Relevant preoperative, intraoperative and postoperative data were collected for the 40 elderly $(\geq 75)$ patients using the abovementioned database and files, and findings in the 2 groups (LITA and non- LITA) were compared. The relevant preoperative data obtained from patient recordings for each case were age, gender, diabetes, family history for coronary artery disease, smoking, history of hypertension, hyperlipidemia, obesity, previous myocardial infarction (MI), cerebrovascular accident, peripheral arterial disease, pulmonary function test results and ejection fraction (Table 1).

The intraoperative and postoperative collected data were intraaortic balloon pulsation (IABP) and inotropic drug support after operation, dysrhythmias, re-exploration for bleeding, atelectasis, pneumothorax, sternal dehiscence, sternal infection, number of distal anastomoses, duration of mechanical ventilation, number of blood product transfusions, aortic crossclamp time, cardiopulmonary by-pass time, duration of chest tube stay, intensive care unit stay, hospital stay and amount of chest tube drainage (Table 2).

Inotropic drug support was decided after ensuring all other measures for low cardiac output state. Intraaortic balloon counterpulsation was indicated for low cardiac output states while having ongoing inotropic drug support. Continuous rhythm monitoring was done in the intensive care unit (ICU) after each operation. A 12-lead electrocardiogram (ECG) was obtained immediately after each operation, on postoperative days 1,2, and 4, and just before hospital discharge. A 12-lead ECG trace was also recorded immediately if a patient showed clinical signs of disrhythmia.

Mechanical complications of CABG related to LITA harvesting were defined as: amount of postoperative bleeding, re-exploration for bleeding, sternal dehiscence and sternal infection. Re-exploration indication for bleeding was drainage of more than $200 \mathrm{ml} /$ hour after the activating clotting time was adequately controlled. None of the study patients required reexploration. Sternal dehiscence was diagnosed by physical and radiologic examination as obtained from patient files. Sternal infection was decided after confirmation by microbiologic studies. There was no in-hospital mortality in either group.

\begin{tabular}{llll}
\hline \multicolumn{4}{l}{ Table 1. Preoperative variables in LITA and non-LITA groups } \\
\hline & $\begin{array}{l}\text { Group 1 } \\
\text { (LITA group) }\end{array}$ & $\begin{array}{l}\text { Group 2 } \\
\text { (non LITA group) }\end{array}$ & p value \\
\hline Age (years) & $76.0 \pm 1.2$ & $77 \pm 2.4$ & 0.07 \\
Male gender & $16(80 \%)$ & $12(60 \%)$ & \\
Family history for CAD & $5(25 \%)$ & $6(30 \%)$ & \\
DM & $3(15 \%)$ & $5(25 \%)$ & \\
HT & $5(25 \%)$ & $5(25 \%)$ & \\
Smoking & $7(35 \%)$ & $10(50 \%)$ & \\
Hyperlipidemia & $9(45 \%)$ & $11(55 \%)$ & \\
Obesity & $11(55 \%)$ & $11(55 \%)$ & \\
Previous MI & $4(20 \%)$ & $8(40 \%)$ & \\
CVA & Non & Non & \\
PAD & Non & Non & 0.075 \\
PFT (FEV1/ FVC ratio) & $80 \pm 7.8$ & $76 \pm 4$ & 0.179 \\
EF \% & $51 \pm 10.8$ & $46.6 \pm 13$ & \\
\hline
\end{tabular}

Data were expressed as Mean \pm SD or $\mathrm{n}(\%)$, LITA Left internal mammary artery, CAD: Coronary artery disease, DM: Diabetes mellitus, HT: Hypertension, MI: Myocardial infarction, CVA: Cerebrovascular accidant, PAD: Peripheral arterial disease, PFT: Pulmonary function tests, EF: Ejection fraction

\begin{tabular}{|c|c|c|c|}
\hline & $\begin{array}{l}\text { Group } 1 \\
\text { (LITA group) }\end{array}$ & $\begin{array}{l}\text { Group } 2 \\
\text { (non LITA group) }\end{array}$ & $\mathbf{p}$ \\
\hline Preop $\mathrm{pO}_{2}(\mathrm{mmHg})$ & $77 \pm 5.3$ & $77 \pm 8,5$ & 0.82 \\
\hline Preop $\mathrm{sO}_{2}(\%)$ & $95 \pm 1.3$ & $95.4 \pm 1.2$ & 0.79 \\
\hline Preop pCO $\mathrm{pCO}_{2}(\mathrm{mmHg})$ & $35 \pm 2.2$ & $36 \pm 2.6$ & 0.66 \\
\hline
\end{tabular}




\section{Surgical Procedure}

We selected from the patient computerized database identical cases with respect to applied surgical procedure by the same surgeon. A median sternotomy was performed on all patients. Cardiopulmonary bypass (CPB) was established in a standardized manner with the use of a roller pump and nonpulsatile flow $\left(2.4 \mathrm{~L} / \mathrm{m}^{2} / \mathrm{min}\right)$. A heparinization protocol of 300 $\mathrm{U}$ per kilogram was followed to maintain a clotting time longer than 400 seconds. Patients were cooled to $32{ }^{\circ} \mathrm{C}$ when distal anastomosis was being performed, and warmed to $36^{\circ} \mathrm{C}$ before weaning from $\mathrm{CPB}$. After aortic cross clamping, cold-blood cardioplegia was accomplished with anterograde delivery through the aortic root for diastolic arrest of the heart initially and after each distal anastomosis intermittently. A final dose of "hot-shot" cardioplegia was also administered antegradely just before the aorta was unclamped. The LITA was harvested by "no-touch" technique as a pedicle with its adjacent veins and surrounding tissue. Hemoclips were used for the control of LITA side branches and electrocautery was used for hemostasis of the sternal surface where the LITA was harvested. Protamine was used to reverse the effects of heparinization.

\section{Statistical Analysis}

Data were analysed using descriptive statistics. Differences between groups were analyzed by unpaired Student $t$ test or the Mann- Whitney U test, when necessary. Within-group variables comparing preoperative versus postoperative values were evaluated by paired Student $t$ tests. Chi-square test was used for comparing ratios between groups. A p value less than 0.05 was considered statistically significant.

\section{RESULTS}

Demographic and preoperative patient characteristics of a total of 40 elderly (age $\geq 75$ ) patients who had undergone CABG with LITA (group 1, $\mathrm{n}=20$ ) or without LITA (group 2, $\mathrm{n}=20$ ) are summarized in Table 1. No statistical differences were found in terms of age, gender, peripheral arterial disease and other values. With respect to frequency of diabetes mellitus, which is a main risk factor for postoperative complications such as sternal dehiscence and infection, the two groups were similar (15\% in group $1,25 \%$ in group 2, respectively). Also another important postoperative risk predictor, pulmonary function test results, were similar in the two groups ( $80 \pm 7.8$ vs $76 \pm 4$, respectively, in group 1 and group 2, $\mathrm{p}=0.075$ ). Preoperative arterial blood gas analysis was compared between the two groups (Table 2). There were no statistically significant differences between them in terms of $\mathrm{pO}_{2}(\mathrm{p}=0.82), \mathrm{sO}_{2}(\mathrm{p}=0.79)$ and $\mathrm{pCO}_{2}(\mathrm{p}=0.66)$.

There were no statistically significant differences between the two groups with respect to CPB time, cross-clamp time or number of distal anastomoses. $\mathrm{P}$ values of these variables are shown in Table 3. In group 1, none of the patients, and in group 2, 1 patient $(5 \%)$, needed IABP support in the postoperative period. This difference between the two groups was not statistically significant $(\mathrm{p}=0.83)$. Need for inotropic drug in the two groups was also similar, $10(50 \%)$ patients in group 1 and $9(45 \%)$ patients in group $2(\mathrm{p}=0.69)$. Dysrhythmia diagnosed by a 12-lead ECG was encountered less frequently in group 1 (in 3 patients, 15\%) than in group 2 (in 7 patients, 35\%) and the $\mathrm{p}$ value was 0.02 . The values related to postoperative bleeding, total amount of chest tube drainage, re-exploration for bleeding and to some extent the number of blood product transfusions,

\begin{tabular}{|c|c|c|c|}
\hline & Group 1 (LITA group) & Group 2 (non LITA group) & p value \\
\hline Inotropic drug need & $10(50 \%)$ & $9(45 \%)$ & 0.69 \\
\hline IABP usage & non & $1(5 \%)$ & 0.83 \\
\hline Dysrythmia & $3(15 \%)$ & $7(35 \%)$ & 0.02 \\
\hline Re-exploration for bleeding & non & non & \\
\hline Atelectasis & $9(45 \%)$ & $10(50 \%)$ & 0.76 \\
\hline Pneumothorax & $3(15 \%)$ & Non & 0.03 \\
\hline Sternal dehiscence & $1(5 \%)$ & Non & 0.047 \\
\hline Sternal infection & $1(5 \%)$ & Non & 0.047 \\
\hline Number of distal anastomosis & $3 \pm 0.7$ & $2.7 \pm 0.8$ & 0.91 \\
\hline Duration of mechanical ventilation (hours) & $5.9 \pm 1.7$ & $6.3 \pm 2.3$ & 0.82 \\
\hline Number of blood product transfusions & $1.8 \pm 1.3$ & $2 \pm 1.7$ & 0.86 \\
\hline Cross clamp time (minutes) & $51.2 \pm 17.5$ & $46.4 \pm 13$ & 0.33 \\
\hline Cardiopulmonary by-pass time (minutes) & $86.6 \pm 25.9$ & $87.5 \pm 24$ & 0.91 \\
\hline Duration of chest tube stay (days) & $1.95 \pm 0.51$ & $1.90 \pm 0.44$ & 0.83 \\
\hline Intensive care unit stay (days) & $2.1 \pm 0.67$ & $2.1 \pm 0.85$ & 0.81 \\
\hline Hospital stay (days) & $9.3 \pm 1.4$ & $9.2 \pm 1.67$ & 0.84 \\
\hline Total amount of chest tube drainage $(\mathrm{mL})$ & $567 \pm 200$ & $555 \pm 307$ & 0.88 \\
\hline
\end{tabular}


were similar in the two groups. Pneumothorax was encountered in 3 patients of group 1 (with LITA group), but none of the group 2 (without LITA group) patients were shown to have pneumothorax ( $3 \%$ vs. $0 \%, \mathrm{p}=0.03)$. On the other hand, two other variables related to pulmonary status, atelectasis and mechanical ventilation time, were similar in the two groups. In group 1, sternal dehiscence was seen in one patient $(5 \%)$ and again in one patient $(5 \%)$ in group 1 sternal infection was seen. Neither sternal dehiscence nor sternal infection were seen in group 2 and the $\mathrm{p}$ value for each variable was 0.047 . Intensive care unit stay and hospital stay were similar for the two groups.

Arterial blood gas analysis dealing with $\mathrm{pO}_{2}, \mathrm{sO}_{2}$ and $\mathrm{pCO}_{2}$ was studied at the time of patient transport to the intensive care unit, just after extubation, at 6 hours after extubation and at 12 hours after extubation. There were no statistically significant differences between the two groups with respect to $\mathrm{pO}_{2}, \mathrm{sO}_{2}$ and $\mathrm{pCO}_{2}$. The $\mathrm{p}$ values are shown in Table 4.

\section{DISCUSSION}

The worldwide population is getting older and more elderly patients are undergoing coronary artery bypass grafting surgery today(4). Being older itself means having more chronic illnesses, such as cerebrovascular disease, history of myocardial infarction, peripheral arterial disease, pulmonary and renal disease, resulting in a higher risk of postoperative complication rates for $\mathrm{CABG}$, as is the case with any other intervention(5). With improvements in cardiac surgical techniques, mortality and morbidity of $\mathrm{CABG}$ while relieving angina effectively in the older population has declined over the years $(6)$.

Left internal thoracic artery use has made coronary artery bypass surgery superior to other interventions for coronary artery stenosis. Saphenous vein grafts have been most commonly used for CABG, but the patency rate is a problem, causing cardiac related deaths frequently between 5 and 10 years after operation(7). LITA, having longer patency rates, has overcome this problem( ${ }^{(8)}$. However, the LITA has not been used by some surgeons in cases of certain relative contraindications, such as left ventricular hypertrophy, severe left ventricular dysfunction, emergency operations, chronic obstructive pulmonary disease with enlarged lungs, and advanced age(9). But in emergent situations, it depends on the experience of the surgeon. Most experienced surgical units can harvest the LITA in a relatively short time, with little or no blood loss, despite the use of intravenous antiplatelet agents from the catheterization laboratory $(10)$. In this study, emergent CABG operations were not included. The bleeding complications in patients who had undergone CABG with LITA, measured by re-exploration for bleeding and total amount of chest tube drainage, were not greater than in cases without use of LITA.

Hurlburt et al.(11), suggested that LITA grafting causes an increase in the incidence of postoperative atelectasis and effusion. Pleural effusion may be encountered at a rate of up to $50 \%$ after $\mathrm{CABG}^{(12)}$. Some authors suggest that this might be related to the LITA harvesting itself leaving a raw surface as a source of serous fluid(13).

LITA harvesting might be a reason for a higher incidence of pulmonary morbidity. The requirement for increased chest wall retraction for better exposure and additional dissection needed to mobilize the LITA pedicle might lead to greater postoperative discomfort with less efficient coughing and pulmonary mechanics(11). In this present study, in contrast to the above-mentioned literature, atelectasis was not found to be more frequent in the LITA group. Berrizbeitia and associates(14) demonstrated a significant deterioration in pulmonary function tests in patients after CABG, and this decrease in function was greater in the group in which the LITA was harvested. Avoiding pleurotomy can be mentioned as an example of a surgical measure for preventing postoperative pulmonary complications. Pleurotomy may confer a better exposure of the LITA and thus lower incidence rates of postoperative pericardial effusion and tamponade. On the other hand, postoperative pulmonary disorders are liable to occur more frequently via pleurotomy. Another aspect of this is that most patients who require $\mathrm{CABG}$ tend to be smokers and thus already suffer from some degree

\begin{tabular}{|c|c|c|c|}
\hline Arterial blood gases & Group 1 (LITA group) & Group 2 (non LITA group) & p value \\
\hline Postop $\mathrm{pO}_{2}(\mathrm{mmHg})$ & $114 \pm 11.9$ & $123 \pm 28$ & 0.38 \\
\hline Postop $\mathrm{sO}_{2}(\%)$ & $98 \pm 0.8$ & $98 \pm 0.7$ & 0.90 \\
\hline Postop $\mathrm{pCO}_{2}(\mathrm{mmHg})$ & $33.7 \pm 9.6$ & $36 \pm 8.8$ & 0.24 \\
\hline Just after extubation $\mathrm{pO}_{2}(\mathrm{mmHg})$ & $67.9 \pm 9.3$ & $64 \pm 8.1$ & 0.41 \\
\hline Just after extubation $\mathrm{sO}_{2}(\%)$ & $9.4 \pm 2.3$ & $92 \pm 1.5$ & 0.63 \\
\hline Just after extubation $\mathrm{pCO}_{2}(\mathrm{mmHg})$ & $33.7 \pm 5.7$ & $34 \pm 4.8$ & 0.87 \\
\hline $6^{\text {th }}$ hour after extubation $\mathrm{pO}_{2}(\mathrm{mmHg})$ & $67 \pm 7.9$ & $64 \pm 7.2$ & 0.29 \\
\hline $6^{\text {th }}$ hour after extubation $\mathrm{sO}_{2}(\%)$ & $93 \pm 1.9$ & $92 \pm 1.7$ & 0.84 \\
\hline $6^{\text {th }}$ hour after extubation $\mathrm{pCO}_{2}(\mathrm{mmHg})$ & $35 \pm 4.5$ & $34 \pm 3.8$ & 0.72 \\
\hline $12^{\text {th }}$ hour after extubation $\mathrm{pO}_{2}(\mathrm{mmHg})$ & $66.9 \pm 7.8$ & $65 \pm 6.3$ & 0.43 \\
\hline $12^{\text {th }}$ hour after extubation $\mathrm{sO}_{2}(\%)$ & $92.6 \pm 1.9$ & $93 \pm 1.2$ & 0.54 \\
\hline $12^{\text {th }}$ hour after extubation $\mathrm{pCO}_{2}(\mathrm{mmHg})$ & $35.5 \pm 3.4$ & $34 \pm 2.2$ & 0.67 \\
\hline
\end{tabular}

Data were expressed as Mean $\pm \mathrm{SD}$, LITA: Left internal mammary artery, $\mathrm{pO}_{2}$ : Partial pressure of oxygen, $\mathrm{pCO}_{2}$ : Partial pressure of carbon dioxide, sO $\mathrm{O}_{2}$ : Oxygen saturation 
of pulmonary disease. As a result, maintaining the pleura intact could reduce the incidence of postoperative respiratory complications in this group of patients(15). In the literature, we found that pulmonary functions were evaluated with pulmonary function tests, but we only screened arterial blood gases as a measure of pulmonary function in each group. There was no significant difference between the two groups in terms of postoperative arterial blood gas analysis.

Sternal dehiscence is a very serious complication after cardiac operations, leading to high morbidity and mortality rates. It may lead to poor pulmonary function due to the instability of the chest wall(16). LITA harvesting may disrupt the blood supply of the sternum, causing healing problems. Use of bone wax and excessive electrocoagulation for hemostasis must be avoided. Some studies suggest that these interventions may make it easier to develop sternal complications, including dehiscence and infection(17). Although we could not obtain any recorded data about bone wax or excessive electrocoagulation, in the LITA group sternal dehisence and infection were seen in two different patients. In the patient who suffered from sternal infection, the reason was methicillin resistant staphylococcus aureus documented by wound culture. This patient was treated for 10 days with antibiotherapy and minor sternal wound debridement. In a systematic review, Zhang et al. concluded that diabetes mellitus is an important risk factor for sternal infection and blood transfusion in patients undergoing $\mathrm{CABG}^{(18) \text {. }}$ In another study, Filsoufi et al. indicated that diabetes is an independent risk factor for sternal infection in the perioperative period(19). Filsoufi et al., in another study, after multivariate analysis demonstrated that obesity $(\mathrm{OR}=2.2)$ is also a predictor of deep sternal wound infection(20). In this study group, diabetes mellitus, obesity and blood transfusion frequency in each group were similar.

Some cardiac surgeons have avoided the use of the LITA graft in elderly patients due to the limited long term survival expectations, and there has been a perception that LITA harvesting in elderly petients may cause considerable increased mechanical complications(21). But in many elderly patients, saphenous veins are poor quality conduits for bypass surgery $(8)$. On the other hand, the number of elderly patients undergoing CABG has risen dramatically and they have a comparable 5 -year survival to younger patients(22).

In this study, we discussed possible mechanical complications of LITA harvesting. It is well known that being older is associated with more comorbidities, in other words, having limited reserves. Therefore, we must clarify whether LITA harvesting is worthwhile or not in older patients.

In older patients, some predisposing factors of sternal infection such as diabetes and osteoporosis are more common. Therefore, avoidance of unnecessary use of electrocoagulation and bone wax are more important to decrease the incidence of sternal dehiscence and infection, especially in older individuals.

In this study, we summarized mechanical complications that are seen, including sternal dehiscence in one patient whose LITA was harvested. Sternal infection was seen in another patient in the LITA group. None of these complications were seen in patients whose LITA was not harvested. These complications were statistically different between the two groups ( $\mathrm{p}=0.047)$. Our two groups were similar in the frequency of diabetes mellitus. Pneumothorax was seen in three patients whose LITA was harvested, but not in any patients of the other group (whose LITA was not harvested) $(\mathrm{p}=0.03)$. There was no other significant differences in other mechanical complications between the two groups.

In conclusion, we believe that mechanical complications related to LITA harvesting are not sufficient to refrain from using this graft in elderly patients. LITA is not a graft that can be easily abandoned but instead, some surgical measures to prevent postoperative mechanical complications must be taken. If this could be carried out, then the advantages of LITA would be greater than the disadvantages.

\section{Study Limitations}

First of all, it was a retrospective study. Although we screened data very carefully, we could not obtain any recorded data concerning pleurotomy and postoperative pulmonary function tests with spirometry. Rather, we found only arterial blood gas analysis postoperatively. Secondly, obesity is an important parameter for sternal complications, but we could not find any data on body mass index. Thirdly, further studies must be designed for larger patient populations.

\section{Acknowledgments}

The authors acknowledge with gratitude the cooperation of people who collected and managed the database of our institution.

\section{CONFLICT of INTEREST}

The authors reported no conflict of interest related to this article.

\section{REFERENCES}

1. Loop FD, Lytle BW, Cosgrove DM, Goormastic M, Taylor PC, Golding LA, et al. Coronary artery bypass graft surgery in the elderly. Indications and outcome. Cleve Clin J Med 1988;55:23-34.

2. Loran DB, Zwischenberger JB. Thoracic surgery in the elderly. J Am Coll Surg 2004;199:773-84.

3. Kay EB, Naraghipour H, Beg RA, DeManey M, Tambe A, Zimmerman HA. Internal mammary artery bypass graft- long term patency rate and follow-up. Ann Thorac Surg 1974;18:269-79.

4. Ricci M, Karamanoukian HL, Abraham R, Von Fricken K, D'Ancona G, Choi S. et al. Stroke in octogenarians undergoing coronary artery surgery with and without cardiopulmonary bypass. Ann Thorac Surg 2000;69:14715 .

5. Moshkovitz Y, Paz Y, Shabtai E, Cotter G, Amir G, Smolinsky AK, et al. Predictors of early and overall outcome in coronary artery bypass without cardiopulmonary bypass. Eur J Cardiothorac Surg 1997;12:31-9.

6. Wilson MF, Baig MK, Ashraf H. Quality of life in octagenarians after coronary artery bypass grafting. Am J Cardiol 2005;95:761-4.

7. Lytle BW, Loop FD, Cosgrove DM, Ratliff NB, Easley K, Taylor PC. Longterm ( 5 to 12 years) serial studies of internal mammary artery and saphenous vein coronary bypass grafts. J Thorac Cardiovasc Surg 1985;89:248-58.

8. Gardner TJ, Greene PS, Rykiel MF, Baumgartner WA, Cameron DE, Casale AS, et al. Routine use of the left internal mammary artery graft in the elderly. Ann Thorac Surg 1990;49:188-94. 
9. Edwards FH, Clark RE, Schwartz M. Impact of the internal mammary artery conduits on operative mortality in coronary revascularization. Ann Thorac Surg 1994;57:27-32.

10. Cohn L. Use of the internal mammary artery graft and in-hospital mortality and other adverse outcomes associated with coronary artery bypass surgery. Circulation 2001;103:483-4.

11. Hurlbut D, Myers ML, Lefcoe M, Goldbach M. Pleuropulmonary morbidity: internal thoracic artery versus saphenous vein graft. Ann Thorac Surg 1990;50:959-64.

12. Areno JP, McCartney JP, Eggerstedt J, Grafton W, George RB. Persistent pleural effusions following coronary bypass surgery. Chest 1998;114:311-4.

13. Kollef MH. Symptomatic pleural effusion after coronary artery revascularization: unsuspected pleural injury from internal mammary artery resection. South Med J 1993;86:585-8.

14. Berrizbeitia LD, Tessler S, Jacobowitz IJ, Kaplan P, BudzilowicL L, Cunningham JN. Effect of sternotomy and coronary bypass surgery on postoperative pulmonary mechanics. Chest 1989;96:873-6.

15. Guizilini S, Gomes WJ, Faresin SM, Bolzan DW, Buffolo E, Carvalho AC et al. Influence of pleurotomy on pulmonary function after off-pump coronary artery bypass grafting. Ann Thorac Surg 200;84:817-22.
16. Molina JE, Lew RS, Hyland KJ Postoperative sternal dehiscence in obese patients: incidence and prevention. Ann Thorac Surg 2004;78:912-7.

17. Baskett RJ, MacDougall CE, Ross DB. Is mediastinitis a preventable complication? A 10-year review. Ann Thorac Surg.1999;67:462-5.

18. Zhang X, Wu Z, Peng X, Wu A, Yue Y, Martin J et al. Prognosis of diabetic patients undergoing coronary artery bypass surgery compared with nondiabetics: a systematic review and meta-analysis. J Cardiothorac Vasc Anesth 2011;25:288-98.

19. Filsoufi F, Rahmanian PB, Castillo JG, Mechanick JI, Sharma SK, Adams DH. Diabetes is not a risk factor for hospital mortality following contemporary coronary artery bypass grafting. Interact Cardiovasc Thorac Surg 2007;6:753-8.

20. Filsoufi F, Castillo JG, Rahmanian PB, Broumand SR, Silvay G, Carpentier A, et al. Epidemiology of deep sternal wound infection in cardiac surgery. $\mathrm{J}$ Cardiothorac Vasc Anesth 2009;23:488-94.

21. Cosgrove DM, Loop FD, Lytle BW, Goormastic M, Stewart RW, Gill CC, et al. Does mammary artery grafting increase surgical risk? Circulation 1985;72:170-4.

22. Horneffer PJ, Gardner TJ, Manolio TA, Hoff SJ, Rykiel MF, Pearson TA, et al. The effects of age on outcome after coronary bypass surgery. Circulation $1987 ; 76 ; 6-12$. 